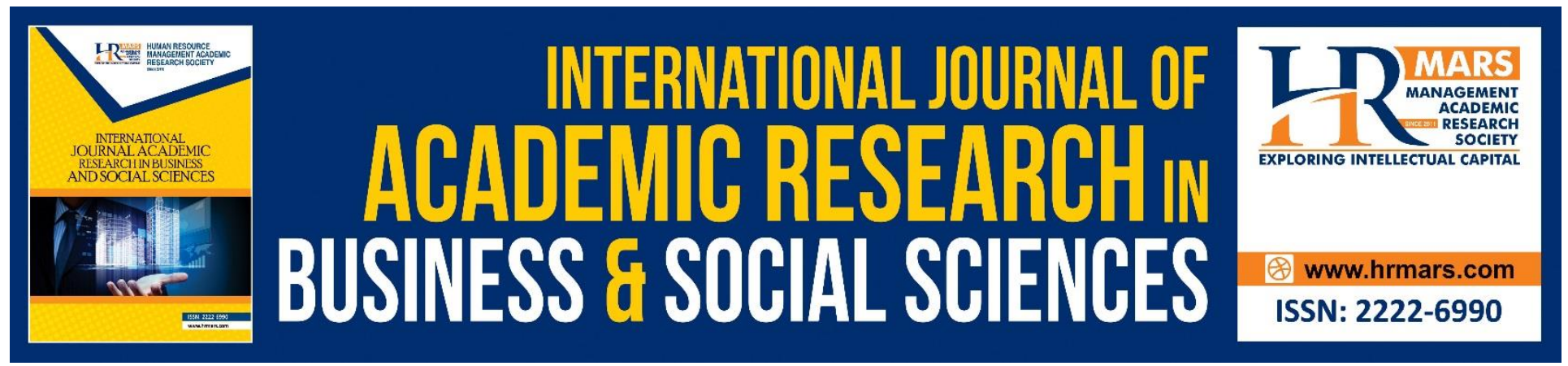

\title{
Financial Self-Efficacy and Entrepreneurial Leadership on SME Performance
}

Achmad Kautsar, Nadia Asandimitra, Tony Seno Aji

To Link this Article: http://dx.doi.org/10.6007/IJARBSS/v8-i12/5326

DOI: $10.6007 /$ IJARBSS/v8-i12/5326

Received: 18 Nov 2018, Revised: 27 Dec 2018, Accepted: 29 Dec 2018

Published Online: 08 Jan 2019

In-Text Citation: (Kautsar, Asandimitra, \& Aji, 2018)

To Cite this Article: Kautsar, A., Asandimitra, N., \& Aji, T. S. (2018). Financial Self-Efficacy and Entrepreneurial Leadership on SME Performance. International Journal of Academic Research in Business and Social Sciences, 8(12), 1806-1816.

Copyright: (C) 2018 The Author(s)

Published by Human Resource Management Academic Research Society (www.hrmars.com)

This article is published under the Creative Commons Attribution (CC BY 4.0) license. Anyone may reproduce, distribute, translate and create derivative works of this article (for both commercial and non-commercial purposes), subject to full attribution to the original publication and authors. The full terms of this license may be seen

at: http://creativecommons.org/licences/by/4.0/legalcode

Vol. 8, No. 12, 2018, Pg. 1806 - 1816

http://hrmars.com/index.php/pages/detail/IJARBSS

JOURNAL HOMEPAGE

Full Terms \& Conditions of access and use can be found at http://hrmars.com/index.php/pages/detail/publication-ethics 


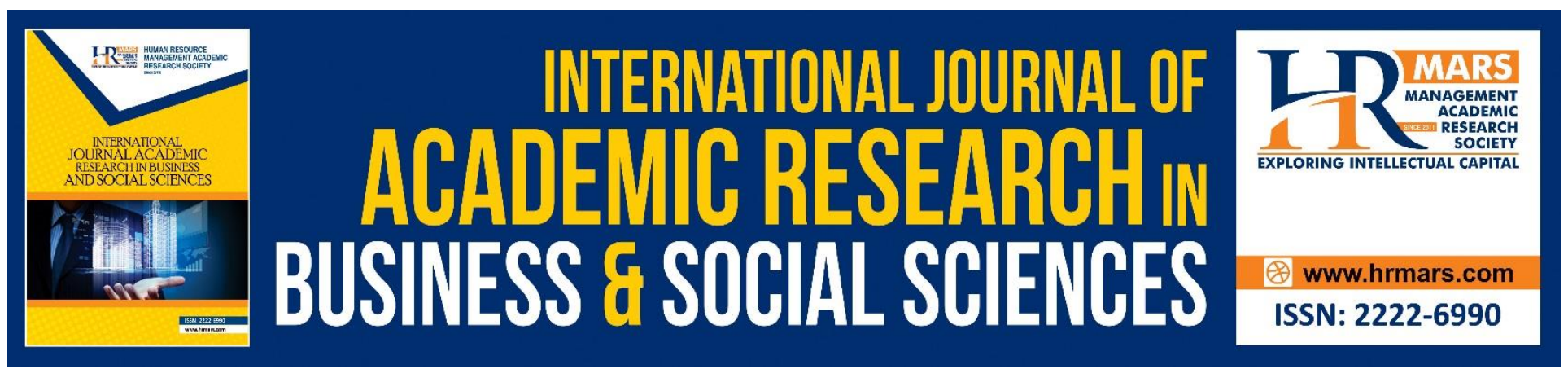

\title{
Financial Self-Efficacy and Entrepreneurial Leadership on SME Performance
}

\author{
Achmad Kautsar \\ Department of Management, Faculty of Economics, Universitas Negeri Surabaya (Unesa), Indonesia, \\ Email: achmadkautsar@unesa.ac.id \\ Nadia Asandimitra \\ Department of Management, Faculty of Economics, Universitas Negeri Surabaya, Indonesia, \\ Email: nadiaharyono@unesa.ac.id

\section{Tony Seno Aji} \\ Department of Economic Sciences, Faculty of Economics, Universitas Negeri Surabaya, Indonesia \\ Email: tonyseno@unesa.ac.id
}

\begin{abstract}
Small, and Medium Enterprises (SME) management is highly dependent on the role of entrepreneurial leadership because it is one of the keys to success in the company. Entrepreneurial leadership is an act of change that leads to the increasing of creativity, innovation, intuition, leadership skills, motivation, and the courage to take risks in an organization. A leader must be able to influence subordinates' behavior so that they can cooperate and work productively to achieve organizational goals.

A number of researchers have studied the success factors for Small, and Medium Enterprises (SMEs) by discussing about human/ social and financial capital. But, it is found that only small numbers of researcher who analyze the role of socio-cognitive factors in the SMEs' success. One of the most important factors is self-efficacy. Self-efficacy is particularly suited for entrepreneurial studies because it builds certain tasks, including an individual's self-esteem, both internal (personality) and external (environmental).

The population of this study is the Alumni of UNESA. The sampling technique is conducted by purposive sampling. Alumni who run a business and graduated at least 2 years before 2017 are chosen as sample. The data analysis technique used is multiple regression analysis. The results of this study conclude that there is influence between entrepreneurial leadership and financial self-efficacy on the performance of micro and small business amongst the alumni.
\end{abstract}

KEYWORDS: Entrepreneurial Leadership, Financial Self-Efficacy, SME Performance 


\section{INTRODUCTION}

The increasing number of SMEs in Indonesia encourages entrepreneurs to become more competitive. SME management is highly dependent on the role of entrepreneurial leadership, because it is one of the success factors in the company. Leadership is the main force that is required to perform a successful change. Leaders must empower their employees to materialize their vision. One of the key factors that influence the success of an entrepreneur in mobilizing others in achieving the goals set by the company is to provide motivation. Research on the performance of SMEs is still interesting now (Wardoyo et al, 2018). According to experts, in this era of rapid change, managers and leaders are required to be more entrepreneurial. Leadership is the main force needed to successfully make changes. Leaders must empower their employees to realize their vision.

According Pattimukay (2008), building the spirit of entrepreneurial leadership is an act of changes aimed at enhancing creativity, innovation, intuition, leadership skills, motivation, and the courage to take risks in the organization. A leader must be able to influence the behavior of subordinates to cooperate and work productively to achieve organizational goals (Hasibuan, 2006). The results of previous studies show that Continuous Improvement, Innovativeness, Pro-activeness and Resources Alocation are the four most important components of entrepreneurial leadership that have a significant impact on the performance of Indian SMEs (Cheda \& Banga, 2013). Mgeni's research (2015) found that entrepreneurial leadership has an influence on business performance in Tanzania. Covin and Slevin (1991) found that entrepreneurial leadership has relevance to the performance and success of a company.

Successful entrepreneurs tend to have education, experience in the industry, and are able to secure sufficient capital to start and operate their SME business. However, it is rare to analyze the role of sociocognitive factors in the success of SMEs. One of the most important factor is self-efficacy. The existence of research or literature that defines and measures self-efficacy is still very rare.

Self-efficacy is particularly suited for entrepreneurial studies because it builds certain tasks, such as individual's self-esteem, both internal (personal) and external (environmental). A study by Krueger et al (2000) found self-efficacy to be a good predictor to encourage opening a business. Meanwhile, research conducted by Markman et al (2002) describes financial self-efficacy as the main determinant of new business growth.

In this study, the SME performance variables are illustrated by the size of the sales, then the factors that influence the successes used in this research are the entrepreneurship leadership and confidence of financial management that have been tested by Cheda \& Banga (2013), Mgeni (2015), Nyamwanza et al (2014), and Amatucci \& Crawley (2011).

\section{LITERATURE REVIEW}

\section{Entrepreneurial Leadership}

According to Covin \& Slevin (2002) and Hitt \& Ireland (2002), entrepreneurial leadership is the ability to influence others to strategically manage resources, with the aim of emphasizing both opportunistic and profit-seeking behavior. According to Corbin (2007), entrepreneurial leadership is the characteristic of leaders who are able to delegate, build employees to behave responsibly, able to make decisions, and work independently. 
Goosen (2007) says that entrepreneurial leadership, both individuals and organizations, creates an entrepreneurial culture by developing entrepreneurship training and incorporation of entrepreneurial processes, as well as brilliant initiatives. According to Winardi (2003) entrepreneurial leadership is an entrepreneur who actively experiments innovatively, and they are skilled at practicing the transformation of attractive possibilities. According to Fernald et al. (2005), there are 8 characteristics of entrepreneurial leadership, namely:

1. Able to motivate

2. Achievement orientated

3. Creative

4. Flexible

5. Patient

6. Persistent

7. Risk Taker

8. Visionary

\section{Financial Self-efficacy}

Bandura $(1977,1986,1997)$ defines self-efficacy as an individual's belief in his ability to succeed in accomplishing specific tasks. According to Bandura (1997), people with a high level of self-efficacy will fight whatever challenges arise and are highly likely to succeed in resolving the challenge.

The self-efficacy theory proposed by Bandura $(1977,1986,1997)$ has an impact on motivation. Selfefficacy is the belief of the individual's ability to achieve the desired outcome. The perception of selfefficacy reflects the individual's optimism of his ability to succeed. Individuals with a high level of selfefficacy believe that they can accomplish difficult tasks and can overcome these difficulties. Selfefficacy facilitates goal setting, business investment, persistence in facing obstacles and rising from adversity. Self-efficacy can be regarded as a positive resistance factor. Self-efficacy is related to motivation as well as behavior, so it is relevant to behavioral change.

Self-efficacy refers to one's assessment of his ability to accommodate the mental resources, motivations, and actions necessary to accomplish a particular task (Gist \& Mitchell, 1992). Bandura and Wood (1989) suggest that self-efficacy is associated with personal control. This statement indicates that low self-efficacy may cause one to focus more on potential failure than the likelihood of success. Research has shown that self-efficacy affects a number of work-related behaviors and attitudes, such as goal aspirations, commitment, and performance (Gist 1987), which may apply to personal finance.

\section{Relevant Researches}

Asandimitra \& Kautsar's (2017) research background is that many researchers have discussed success factors for SMEs by discussing human as well as social and financial capital (Caputo and Dolinsky, 1998; Chandler and Hanks, 1998; Carter et al., 1997) , but it is still rare to find researcher who analyze the role of sociocognitive factors in the success of SMEs. The most important factor that is selfconfidence on one's own ability, or so-called self-efficacy, is still not widely researched so that the literature is still limited. 
In this study, the success variable is illustrated by the amount of business sales. Factors that influence the success used in this study are age, education, work experience, business age, company size, and financial management capabilities previously tested by Nyamwanza et al (2014) as well Amatucci \& Crawley (2011). By involving self-efficacy in finance, this study is different from others because it combines entrepreneurship theory and behavioral finance theory.

This research was conducted by examining the conception of a successful business woman by testing the relationship between age, education, work experience, age of business, company size, and beliefs related to Financial self-efficacy that influence the success of SME business by using moment correlation product from Karl Pearson and formulating a successful business model led by businesswoman. The results of data analysis showed that the age of the entrepreneur as well as the age of business can influence the success of SME management run by women entrepreneurs. While education, work experience, and number of employees have no significant effect. The latest analysis shows that there is a positive significance between financial self-efficacy towards the success of SMEs among women entrepreneurs.

Based on research by McMahon (2001) on the characteristics of financial management on business growth and performance between small and medium enterprises (SMEs) engaged in manufacturing, the result of corporate financial characteristics appear to have a dominant impact on SMEs achievement. In addition, the size of the company is significantly related to the performance of the company.

The Amatucci \& Crawley (2011) states that as the number of businesswomen increases worldwide, it is increasingly important to understand the factors that contribute to their success. Although entrepreneurial research identifies access to human capital and finance as important, studies that explore the role of social cognitive factors such as self-efficacy are very few. This study aims to examine gender relevance to financial management based on previous research, cognitive psychology and entrepreneurship. The results are only partially proving that a lack of confidence combined with anxiety has an impact on financial management. While differences in age and race significantly impact on financial self-efficacy.

Nyamwanza et.al (2014) states that the informal sector is the main driver in the Zimbabwean economy, but the contribution of this sector becomes meaningless due to non-compliance in tax payments. The study was conducted on 50 businesses in the retail sector in Gweru. The result is the efforts made to enforce compliance are too minimal and the corruption among tax officers are too high. SMEs evade taxes by paying bribes, storing two sets of records, moving to new places without notifying authorities, and temporarily closing businesses during the compliance blitz. Punishment has proven most effective in enforcing compliance. Publicity should be upgraded by the authorities using radio, television, and pamphlets, which are most effective. In addition, the Zimbabwe Revenue Authority (ZIMRA) should provide tax education to businesses to improve understanding of tax obligations and compliance.

Chheda \& Banga (2013) conducted a study examining the impact of entrepreneurial leadership on the performance of Small and Medium Enterprises in India. The questionnaire method is used to collect information from 67 registered and unregistered SMEs. The questionnaire response was submitted through two stages of analysis. First, exploratory factor analysis was conducted to identify components of comprehensive entrepreneurial leadership. Second, Ordinary Least Square 
Regression (OLS) is conducted to examine the impact of these broad components on company performance. The result of factor analysis identifies six components of entrepreneurial leadership followed by multiple regression analysis.

The Mgeni study (2015) tries to explore the extent to which entrepreneurial leadership is used by SME CEOs in Tanzania. This study also tries to find a link between entrepreneurial leadership and the performance of SMEs in Tanzania. This study is based on primary data collected with questionnaires sent and analyzed quantitatively using Pearson Correlation product moment and simple regression by SPSS. The results show that $68.88 \%$ of the total number of CEOs in Tanzania uses entrepreneurial leadership. Moreover, there was a significant positive correlation between entrepreneurial leadership and business performance of SMEs in Tanzania.

The Covin \& Slevin (2001) study outlines the conceptual model of entrepreneurship as an organizational level phenomenon. This model is intended to describe the organizational system elements associated with entrepreneurial behavior among large corporations, but it may also be applicable in various levels of small firms. Entrepreneurship is described as the induction of strategic posture demonstrated by the risk-taking tendencies of firms, tends to act with aggressive and proactive attitudes, and relies on frequent and extensive product innovations. The proposed model describes the antecedents and consequences of the entrepreneurial posture as well as the variables that moderate the relationship between entrepreneurial posture and firm performance. The advantages of a firm's behavior perspective on entrepreneurship are discussed along with theoretical and managerial implications of that perspective.

\section{METHODOLOGY}

The approach used is quantitative research. This research is designed as an explanation research to explain the subject of the influence of entrepreneurial leadership with financial self-efficacy on the performance of SMEs. The population of this study is the UNESA Alumni. The sampling technique is done by purposive sampling, with the criteria of alumni who run the business and graduated at least 2 years before 2017. The data analysis technique used is multiple regression analysis with the following equation:

SME Performance $=\alpha+\beta 1$ entrepreneurial leadership $+\beta 2$ financial self-efficacy + e ...... (1)

\section{RESULTS}

Validity test results are analyzed by comparing the arithmetic $r$ value (in the Correlated Item-Total Correlation column) with $r$ table ( $d f=n-k$ ). If $r$ arithmetic $>r$ table, then it is declared valid, and if $r$ arithmetic $<$ r table, then declared invalid.

From table 5.1 and table 5.2, it is seen that all items of question indicate that $r$ arithmetic $>r$ table so that it can be concluded that all question items are declared valid. 
INTERNATIONAL JOURNAL OF ACADEMIC RESEARCH IN BUSINESS AND SOCIAL SCIENCES

Vol. 8, No. 12, Dec, 2018, E-ISSN: $2222-6990$ C 2018 HRMARS

Table 5.1. Validity Test of Entrepreneurial Leadership

\begin{tabular}{|l|r|r|c|}
\hline & r arithmetic & \multicolumn{1}{c|}{$r$ table } & Validity \\
\hline X1.1 & .477 & 0.312 & Valid \\
X1.2 & .469 & 0.312 & Valid \\
X1.3 & .556 & 0.312 & Valid \\
X1.4 & .546 & 0.312 & Valid \\
X1.5 & .356 & 0.312 & Valid \\
X1.6 & .690 & 0.312 & Valid \\
X1.7 & .503 & 0.312 & Valid \\
X1.8 & .327 & 0.312 & Valid \\
\hline
\end{tabular}

Source: SPSS output

Table 5.2. Validity Test of Self Financial Efficacy

\begin{tabular}{|l|r|r|c|}
\hline & r arithmetic & r table & Validity \\
\hline X2.1 & .370 & 0.312 & Valid \\
X2.2 & .411 & 0.312 & Valid \\
X2.3 & .358 & 0.312 & Valid \\
X2.4 & .576 & 0.312 & Valid \\
X2.5 & .783 & 0.312 & Valid \\
X2.6 & .755 & 0.312 & Valid \\
\hline
\end{tabular}

Source: SPSS output

Reliability Test Results shows a construct or variable is declared reliable if Cronbach Alpha value> 0.60 (Ghozali, 2006). From table 5.3 shown Cronbach Alpha value $>0.60$, so it can be concluded that the construct question is reliable.

Table 5.3. Reliability Test

\begin{tabular}{|r|c|c|}
\hline & Cronbach's Alpha & $\begin{array}{c}\text { Cronbach's Alpha Based } \\
\text { on Standardized Items }\end{array}$ \\
\hline Entrepreneurial Leadership & .778 & .788 \\
\hline Self Financial Efficacy & .787 & .781 \\
\hline
\end{tabular}

Source: SPSS output

To test whether or not the influence of independent variables on the dependent variable ( $\mathrm{Y}$ ) one by one, $\mathrm{t}$ test is used. If Sig $>0.05$ then Ho is accepted, and if Sig <0,05 then Ho is rejected. The entrepreunerial leadership variable is $0.001<0.05$ then Ho is rejected, meaning there is influence between entrepreneurial leadership and business performance. Self financial eficacy variable is 0,038 $<0,05$ then $\mathrm{Ho}$ is rejected, meaning there is influence between self financial eficacy with business performance. 
INTERNATIONAL JOURNAL OF ACADEMIC RESEARCH IN BUSINESS AND SOCIAL SCIENCES Vol. 8, No. 12, Dec, 2018, E-ISSN: 2222-6990 @ 2018 HRMARS

Table 5.6. $\mathrm{t}$ Test

\begin{tabular}{|c|c|c|c|c|c|c|}
\hline \multirow{2}{*}{\multicolumn{2}{|c|}{ Model }} & \multicolumn{2}{|c|}{$\begin{array}{c}\text { Unstandardized } \\
\text { Coefficients }\end{array}$} & \multirow{2}{*}{$\begin{array}{c}\text { Standardized } \\
\text { Coefficients } \\
\text { Beta }\end{array}$} & \multirow[t]{2}{*}{$\mathrm{T}$} & \multirow[t]{2}{*}{ Sig. } \\
\hline & & $B$ & Std. Error & & & \\
\hline \multirow{3}{*}{1} & (Constant) & -1.234 & .787 & & -1.567 & .124 \\
\hline & ENT_LEAD & .881 & .261 & .434 & 3.372 & .001 \\
\hline & SELF_FIN_EFI & .421 & .198 & .275 & 2.132 & .038 \\
\hline
\end{tabular}

Source: SPSS output

\section{DISCUSION}

The results showed that there was a positive influence between entrepreneurial leadership and business performance. The higher the level of entrepreneurial leadership in the academic community of Economics Faculty, Universitas Negeri Surabaya, resulted in business performance increasing. Entrepreneurial leadership is an opportunity-oriented leadership style, which able to create opportunities, also organize and control resources strategically to achieve profit. According to Fernald et al. (2005), there are 8 characteristics of entrepreneurial leadership, i.e.: able to motivate, achievement oriented, creative, flexible, patient, persistent, risk taker, and visionary. The characteristics of entrepreneurial leadership are very positive and will normatively support business performance. When entrepreneurial leadership is improved, it is only natural that business performance also increases.

Empirically, the research on small business actors in the Economics Faculty of Universitas Negeri Surabaya is in line with the research of Mgeni (2015), who found that $68.88 \%$ of CEOs in Tanzania used leadership style, and found a strong relationship between entrepreneurial leadership and business performance in small, and medium enterprises (SMEs) in Tanzania. Lestari (2014) found that the elements such as: able to motivate, achievement oriented, persistence, risk taking, and visionary affect the performance of employees with a positive direction, thus increasing the company's performance. Lina (2014) also found that leadership has a positive direction on performance. Fransiska and Hutomo (2014) stated that entrepreneurial leadership variable gives 40,3\% influence to employee performance. Entrepreneurial leadership influence and determine the performance of employees at PT Tiga Putra Adhi Mandiri, this shows that the higher entrepreneurial leadership applied in the company, it will improve employee performance.

The results showed that there is a positive influence between financial self-efficacy on business performance. The higher the financial self-efficacy in the academic community at Economics Faculty Universitas Negeri Surabaya will cause business performance to increase as well. Self-efficacy refers to one's assessment of his ability to activate the mental resources, motivations, and actions necessary to accomplish a particular task (Gist \& Mitchell, 1992). The results in this study are in accordance with self-efficacy theory proposed by Bandura $(1977,1986,1997)$. Self-efficacy is the belief of the individual's ability to achieve the desired outcome. The perception of self-efficacy reflects the individual's optimistic belief in his ability to succeed. Individuals with a high level of self-efficacy confidence that they can accomplish difficult tasks and can overcome these difficulties. Self-efficacy 
facilitates goal setting, business investment, persistence in facing obstacles and rising from adversity. Self-efficacy can be considered a positive motivational resource factor.

The results of this study are in accordance with empirical results from Carter et al (2016) who found that self-efficacy affect the performance. Zuhir et al (2017) examines SMEs and found an influence between self-efficacy on the performance of SMEs in Malaysia. Khedhaouria, Gurau, Torres (2015) found that creativity and self-efficacy have an impact on the performance of small firms with variation of entrepreneurial orientation mediation. Sebayang and Sembiring (2017) revealed that there is influence between self-esteem and self-efficacy on performance, either simultaneously or partially. Salman et al (2016) in his study in Pakistan found that self-efficacy has a strong correlation with the performance of workers in the health sector. Purnomo and Lestari (2010), Jacob Cherian (2013), Wahap et al (2015), describes the relationship between self-efficacy and performance.

\section{CONCLUSION}

The implication of this research is that an SME owner must have the behavior and characteristics that support the success of his business. In this study, the thing that must be owned by an SME owner is leadership in entrepreneurship and having confidence in making financial decisions. Both variables have given significant positive results. The results of this study are in accordance with the theory of planned behavior. The theory of planned behavior is a theory that emphasizes the rationality of human behavior as well as the belief that behavioral targets are under the control of individual consciousness (Ajzen, 1988). If we associate with the theory, financial beliefs can encourage IKM users to make good financial decisions, and with entrepreneurial leadership will also have a positive impact on business performance.

\section{REFERENCES}

Amatucci, F.M. and Crawley, D.C. (2011). Financial Self-Eficacy Among Women Entrepreneurs. International Journal of Gender and Entrepreneurship, Vol 3 (1) $23-37$

Asandimitra, N. and Kautsar, A. (2017). Financial Self-Efficacy on Women Entrepreneurs Success. International Journal of Academic Research in Business and Social Sciences, Vol. 7, No. 11

Ajzen, I. (1988). Attitudes, Personality and Behaviour. England: Open University Press.

Bandura, A. (1997) Self-efficacy: Toward A Unifying Theory of Behavioral Change. Psychological Review, vol 84, pp 191-215.

Caputo, R.K. and Dolinsky, A. (1998). Women's Choice to Pursue Self-Employment: The Role of Financial and Human Capital of Household Members.Journal of Small Business Management, Vol. 36 No. 3, pp. 8-18.

Carter, N., Williams, M. and Reynolds, P. (1997). Discontinuance among New Firms in Retail: The Influence of Initial Resources, Strategy, and Gender. Journal of Business Venturing, Vol. 12, pp. 125-45.

Carter, W. R., Nesbit, P. L., Badham, R. J., Parker, S. K., \& Sung, L. K. (2016). The effects of employee engagement and self-efficacy on job performance: a longitudinal field study. International Journal of Human Resource Management, 1-20. DOI: 10.1080/09585192.2016.1244096 
INTERNATIONAL JOURNAL OF ACADEMIC RESEARCH IN BUSINESS AND SOCIAL SCIENCES

Vol. 8, No. 12, Dec, 2018, E-ISSN: 2222-6990 @ 2018 HRMARS

Chandler, G. and Hanks, S.H. (1998). An Examination of The Substitutability of Founders' Human and Financial Capital in Emerging Business Ventures. Journal of Business Venturing. Vol. 13, pp. 353-69

Cherian, J. \& Jolly, J. (2013). Impact of Self Efficacy on Motivation and Performance of Employees, International Journal of Business and Management. Vol. 8, No. 14; 2013

Chheda, K. \& Banga, C. (2013). Impact of Entrepreneurial Leadership on Performance of Small and Medium Enterprises in India. Journal of Asia Entrepreneurship and Sustainability. Vol XI Iss 2

Corbin, B. (2007). Entrepreneurial Leadership - Fundamental_Finance, (online), www.redsamara.com, 28 Desember 2016

Covin, J., and Slevin, D. (1991). A Conceptual Model of Entrepreneurship as Firm Behavior. Entrepreneurship: Theory and Practice, 16(1), 7-24.

Covin, J. G., \& Slevin, D. P. (1988). The Influence of Organization Structure on The Utility of an Entrepreneurial Top Management Style. Journal of Management Studies. 25(3), 217-34.

Fauzi. (1995). Kamus Akuntansi Praktisi. Surabaya

Fernald, L.W., Solomon, G.T., and Tarabishy, A. (2005). A new paradigm: Entrepreneurial leadership. Southern Business Review, 30(2), 1-10.

Hutomo, F. (2014). Analisis Pengaruh Entrepreneurial Leadership dan Motivasi Kerja terhadap Kinerja Karyawan PT Tiga Putra Adhi Mandiri. Binus Business Review. Vol 5 No 1, Mei

Ghozali, I. (2006). Aplikasi Analisis Multivariate Dengan Program SPSS. Cetakan Keempat. Semarang: Badan Penerbit Universitas Diponegoro.

Gist, M.E. (1987), Self-Efficacy: Implications for Organizational Behavior and Human Resource Management. Academy of Management Review. Vol. 12 No. 3, pp. 472-85.

Goossen, R. (2007). Entrepreneurial Excellence. USA: Book Mart Press

Hasibuan, M. (2006). Manajemen Dasar, Pengertian, dan Masalah. Edisi Revisi. Jakarta: Bumi Aksara. Hitt, M. A., and Ireland, R. D. (2002). The essence of strategic leadership: Managing human and social capital. Journal of Leadership and Organization Studies. 9(1): 3- 14.

Khedhaouria A, Gurău G \& Torrès O. (2015). Creativity, Self-Efficacy, and Smallfirm Performance: The Mediating Role of Entrepreneurial Orientation. Small Business Economics, An Entrepreneurship Journal, Volume 44 Number 3. DOI 10.1007/s11187-014-9608-y

Krueger, N.F., Reilly, M.D. and Carsrud, A.L. (2000). Competing models of entrepreneurial intentions. Journal of Business Venturing, Vol. 15 Nos 5-6, pp. 411-32.

Lestari, A. (2014). Pengaruh Entrepreneurial Leadership Terhadap Kinerja Karyawan (Studi Kasus Pada Head Office PT Bank XYZ Indonesia). Abstrak. http://download. portalgaruda.org/article. php?article=168883\&val=4096\&title=Pengaru h\%20Entrepreneurial\%20Leadership\%20Terhadap\%20Kinerja\%20Karyawan\%20(Studi\% 20Kasus\%20pada\%20PT\%20Bank\%20XYZ\%20Indonesia) . Diakses 12 Nopember 2017

Lina, D. (2014). Analisis Pengaruh Kepemimpinan dan Budaya Organisasi terhadap Kinerja Pegawai dengan Sistem Reward Sebagai Variabel Moderating. Jurnal Riset Akuntansi dan Bisnis. Vol 14 No.1. 
INTERNATIONAL JOURNAL OF ACADEMIC RESEARCH IN BUSINESS AND SOCIAL SCIENCES

Vol. 8, No. 12, Dec, 2018, E-ISSN: 2222-6990 @ 2018 HRMARS

Markman, G.D., Balkin, D.B. and Baron, R.A. (2002), Inventors and new venture formation: the effects of general self-efficacy and regretful thinking. Entrepreneurship Theory and Practice, Vol. 27 No. 2, pp. 149-66.

McMahon, R. G. P. (2001). Growth and Performance of Manufacturing SMEs : The Influence of Financial Management Characteristics. International Small Business Journal, 19, 3:10-28

Mgeni, T. O. (2015). Impact of Entrepreneurial Leadership Style on Business Performance of SMEs in Tanzania. Journal of Entrepreneurship \& Organization Management. 4:142. doi:10.4172/ 2169-026X.1000142

Mulyadi. (2001). Sistem Akuntansi, Edisi Ketiga, Cetakan Ketiga. Jakarta: Salemba Empat.

Nyamwanza, T., Mavhiki, S., Mapetere, D., and Nyamwanza, L. (2014). An Analysis of SMEs' Attitudes and Practices Toward Tax Compliance in Zimbabwe. Sage Open. https://doi.org/10.1177/2158244014542776

Pattimukay, H. V. R. (2008). Membangun Jiwa Entrepreneurship dalam Organisasi (Suatu Proses Kepemimpinan Organisasi). Jurnal Membangun Jiwa Entrepreneurship.

Wardoyo, D. T., Iriani, S. S., and Kautsar, A. (2018). Adoption of E-Commerce, Entrepreneurship Orientation Mediated by Business Strategy on The Performance Food Industries. International Journal of Civil Engineering and Technology, Vol 9, Issue 5, pp 896-902.

Winardi, J. (2008). Entrepreneur dan Entrepreneurship. Jakarta: Kencana. 